\title{
PENDEKATAN QSPM SEBAGAI DASAR PERUMUSAN STRATEGI PENINGKATAN PENDAPATAN ASLI DAERAH KABUPATEN BATANG, JAWA TENGAH
}

\author{
Siti Nurhayati \\ Fakultas Ekonomi Universitas Pekalongan, Jawa Tengah \\ E-mail: sitinurhayat@yahoo.co.id
}

\begin{abstract}
The aim of this research is to analyse of increasing Local Original Income (LOI) strategy and his influence to increasing the regional income. The research was done at Local Government Income of Batang regency. This research also want to know that the LOI strategy was based on the potencies and opportunities. The analyzing use the IFE, EFE, SWOT, and then QSPM to choose strategic formulation; and proportion models. The result of Internal - External analysis show that increasing strategy of LOI have not based on the potencies and opportunities that they have yet. The Local Government Income of Batang Regency needs the intensification strategy for increasing the LOI. By the QSPM analysis, the Local Government Income of Batang Regency needs extensification strategy for LOI acceptance.
\end{abstract}

Key words: local original income, internal factor evaluation, external factor evaluation, strategic planning matrix

\section{PENDAHULUAN}

Pelaksanaan otonomi daerah sesuai dengan ketentuan Undang-undang Nomor 32 Tahun 2004 yang didukung dengan Undang-Undang Nomor 33 Tahun 2004, menggariskan bahwa Pemerintah Daerah diberi kesempatan untuk menggali sumber-sumber keuangan baru sesuai dengan potensi setempat. Penyelenggaraan otonomi daerah yang demikian ini mendorong terwujudnya kemandirian dari setiap daerah otonom.

Kemandirian suatu daerah dapat terwujud apabila semua keperluan pembiayaan daerah baik pengeluaran rutin maupun pengeluaran pembangunan dapat dibiayai dengan kemampuan keuangan daerah. Secara makro, kemampuan keuangan daerah dapat dikaji dari sumber-sumber penerimaan daerah yang tertuang dalam Anggaran Pendapatan dan Belanja Daerah (APBD). Penerimaan daerah terdiri atas penerimaan yang berasal dari daerah sendiri (Pendapatan Asli Daerah/PAD), penerimaan yang berasal dari Pemerintah Pusat dalam bentuk dana perimbangan, dan lain-lain pendapatan yang sah. (Halim, 2001)

Sesuai dengan ketentuan yang ada dalam Undang-undang Nomor 32 Tahun 2004, setiap daerah memiliki kewenangan untuk mengoptimalkan penerimaan daerah yang berasal dari PAD yang terdiri atas pajak daerah, retribusi daerah, hasil perusahaan daerah dan hasil pengembalian kekayaan daerah 
Tabel 1. PAD dan Kontribusinya terhadap Penerimaan Daerah Kabupatren Batang Tahun $2001-2005$

\begin{tabular}{cccc}
\hline Tahun & PAD & Pend. Daerah (Rp) & Kontribusi (\%) \\
\hline 2001 & 14.368 .778 .354 & 238.605 .693 .835 & 6,02 \\
2002 & 21.384 .881 .331 & 250.675 .578 .548 & 8,53 \\
2003 & 23.308 .567 .615 & 279.676 .191 .991 & 8,33 \\
2004 & 23.610 .802 .614 & 289.568 .879 .136 & 8,41 \\
2005 & 23.301 .040 .806 & 306.379 .928 .730 & 7,60 \\
\hline
\end{tabular}

Sumber: Laporan Perhitungan APBD Kab. Batang Tahun 2001 - 2005

yang dipisahkan, serta lain-lain PAD yang sah (Muluk, 2003).

Selama kurun waktu 5 Tahun terakhir, realisasi penerimaan PAD dan kontribusinya terhadap pendapatan daerah Kabupaten Batang dapat disajikan dalam Tabel 1.

Berdasarkan data pada tabel tersebut dapat diketahui bahwa kenaikan PAD tidak seimbang dengan kenaikan pendapatan daerah, sehingga kontribusinya belum stabil. Kondisi ini antara lain disebabkan oleh strategi yang ditetapkan untuk penarikan PAD belum didasarkan pada kekuatan, peluang dan potensi yang ada di daerah seperti kerjasama lintassektor, komitmen pengelola PAD, standar pelayanan minimal dan sebagainya (Dewi, 2002).

Rumusan masalah dalam penelitian ini yaitu apakah strategi peningkatan PAD sudah sesuai dengan potensi dan peluang yang ada di Kabupaten Batang?, kemudian rumusan strategi apa yang paling tepat untuk meningkatkan PAD Kabupaten Batang?

Sedangkan alur pemikiran dalam penelitian ini nampak dalam Gambar 1.

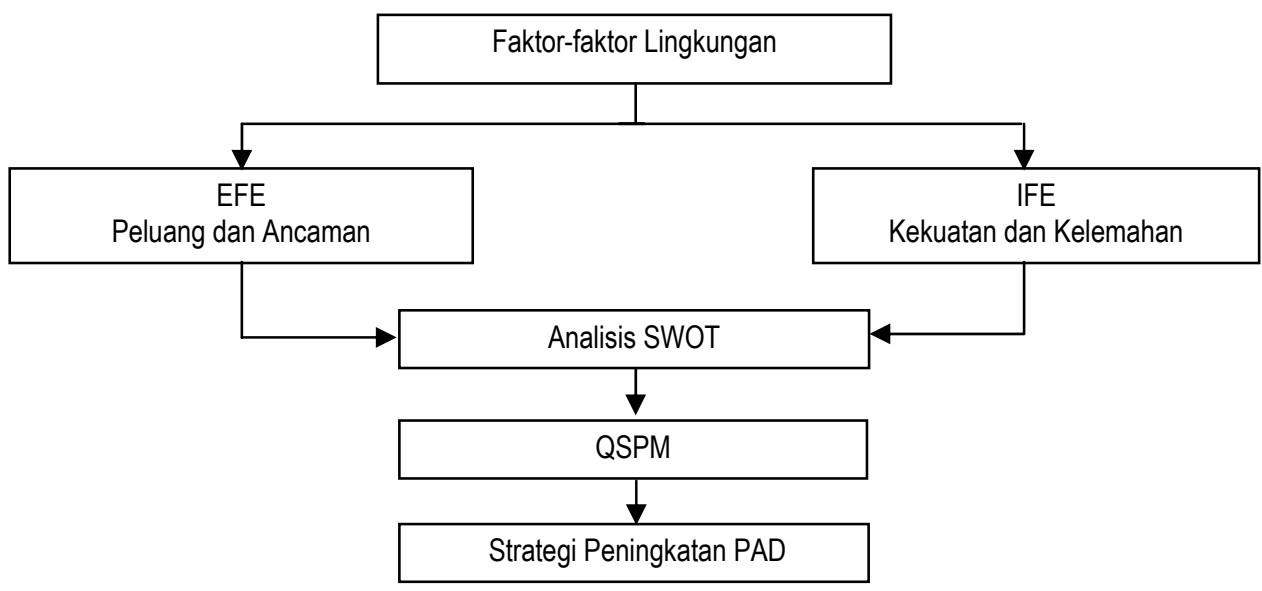

Gambar 1. Alur Kerangka Pemikiran 
METODE PENELITIAN

\section{Jenis dan Obyek Penelitian}

Pendekatan Quantitative Strategic Planning Matrix (QSPM) (David, 2001; Setiawan, 2005) sebagai dasar perumusan strategi peningkatan pendapatan daerah Kabupaten Batang. Penelitian ini merupakan sebuah penelitian deskriptif, yang dimaksudkan untuk melakukan pengukuran secara cermat terhadap fenomena yang ada tanpa harus menguji hipotesis. Penelitian ini dilakukan pada Dinas Pengelola Anggaran Pendapatan
Daerah Kabupaten Batang, yakni pada Bagian Keuangan Sekretariat Daerah dan Dinas Pendapatan Daerah.

\section{Operasionalisasi Variabel}

Variabel yang dioperasikan dalam penelitian ini dapat dijelaskan secara rinci tentang konsep variabel maupun indikator variabel sebagaimana disajikan dalam Tabel 2.

\section{Model Analisis}
a. Matriks External Faktor Evaluation (EFE)

Tabel 2. Jenis, Konsep, dan Indikator Variabel

\begin{tabular}{|c|c|c|}
\hline Jenis Variabel & Konsep Variabel & Indikator \\
\hline Pendapatan Daerah & $\begin{array}{l}\text { Hak Pemda yang diakui sebagai } \\
\text { Penambah nilai kekayaan bersih } \\
\text { dalam periode tahun bersangkutan }\end{array}$ & $\begin{array}{l}\text { a. PAD } \\
\text { b. Dana perimbangan } \\
\text { c. Lain-lain pendapatan }\end{array}$ \\
\hline PAD & $\begin{array}{l}\text { Pendapatan yang bersumber dari } \\
\text { Potensi yang ada di daerah sendiri }\end{array}$ & $\begin{array}{l}\text { a. Pajak daerah } \\
\text { b. Retribusi daerah } \\
\text { c. Hasil pengelolaan kekayaan } \\
\text { daerah } \\
\text { d. Lain-lain PAD yang sah }\end{array}$ \\
\hline $\begin{array}{l}\text { Kekuatan (Strength) dan } \\
\text { Kelemahan (Weakness) }\end{array}$ & $\begin{array}{l}\text { Faktor internal yang dapat menambah } \\
\text { atau mengurangi kemampuan kinerja } \\
\text { Dinas Pengelola Pendapatan }\end{array}$ & $\begin{array}{l}\text { a. SDM } \\
\text { b. Lingkungan kerja } \\
\text { c. Prosedur/sistem } \\
\text { d. Sarana/prasarana } \\
\text { e. Keuangan } \\
\text { f. Manajemen }\end{array}$ \\
\hline $\begin{array}{l}\text { Peluang } \\
\text { (Opportunities) }\end{array}$ & $\begin{array}{l}\text { Faktor eksternal yang menguntungkan } \\
\text { dan dapat dimanfaatkan oleh Dinas } \\
\text { Pengelola Pendapatan }\end{array}$ & $\begin{array}{l}\text { a. Loyalitas objek PAD } \\
\text { b. Dukungan masyarakat } \\
\text { c. Kerjasama lintas sektor dan } \\
\text { program } \\
\text { d. Dukungan yuridis }\end{array}$ \\
\hline Ancaman (Threats) & $\begin{array}{l}\text { Faktor eksternal yang dapat } \\
\text { mengganggu kinerja dinas pengelola } \\
\text { pendapatan }\end{array}$ & $\begin{array}{l}\text { a. Tuntutan mutu pelayanan } \\
\text { b. Rendahnya kesadaran } \\
\text { c. Rendahnya kualitas SDM } \\
\text { penarik pajak } \\
\text { d. Perekonomian yang belum stabil } \\
\text { e. Kebijakan politis }\end{array}$ \\
\hline
\end{tabular}


Matriks ini menyajikan berbagai faktor lingkungan eksternal yang perlu dipertimbangkan dalam upaya peningkatan PAD Kabupaten Batang, disajikan pada Tabel 2.

\section{b. Matrik Internal Factor Evalution (IFE)}

Matriks ini menyajikan berbagai faktor lingkungan internal yang perlu dipertimbangkan dalam upaya peningkatan PAD Kabupaten Batang, disajikan pada Tabel 3. c. Matriks Eksternal dan Internal (EI Matrix)

Dalam matriks Eksternal Internal ini disusun dengan meletakkan total bobot skor EFE pada sumbu tegak dan total bobot skor IFE pada sumbu datar dengan skala setiap sumbu berkisar antara angka 1,00 sampai dengan 4,00. Matriks EI ini dibagi menjadi 3 bagian yaitu:

1) divisi yang berada pada sel I, II, dan IV menunjukkan strategi pengembangan dan membangun (Growth and Build)

Tabel 3. Matrik External Faktor Evaluation (EFE)

\begin{tabular}{|c|c|c|c|c|}
\hline No & External Key Factors & Weight & Rating & Score \\
\hline $\begin{array}{l}1 \\
2 \\
3 \\
4 \\
1 \\
2 \\
3 \\
4\end{array}$ & $\begin{array}{l}\text { Opportunities } \\
\text { Threats }\end{array}$ & $\mathrm{Ai}$ & $\mathrm{Bi}=1,2,3,4$ & $\mathrm{Ai} \times \mathrm{Bi}$ \\
\hline & Total & $\sum A i=1,00$ & & $\sum(\mathrm{Ai} \times \mathrm{Bi}$ \\
\hline
\end{tabular}

Tabel 4. Matrik Internal Factor Evalution (IFE)

\begin{tabular}{llllll}
\hline No & Internal Key Factors & & Weight & Rating & Score \\
\hline & Strength & $\mathrm{Ai}$ & $\mathrm{Bi}=1,2,3,4$ & $\mathrm{Ai} \times \mathrm{Bi}$ \\
1 & & & & \\
2 & & & & \\
3 & & & & \\
4 & & & & \\
1 & Weakness & & & \\
2 & & & & \\
3 & & & & \\
4 & & $\sum \mathrm{Ai}=1,00$ & $\mathrm{Ai} \times \mathrm{Bi})$ \\
\hline
\end{tabular}


2) divisi yang berada pada sel III, V, dan VII dapat melaksanakan strategi mempertahankan dan memelihara (Hold and Maintain)

3) divisi yang berada pada sel VI, VIII, dan IX menunjukkan strategi mengambil hasil atau melepaskan (Harvest or Divest)

\section{d. Matrik SWOT}

Matriks SWOT menggambarkan berbagai alternatif strategi yang berasal dari kajian secara komprehensif antara faktor lingkungan internal dan eksternal, yang kemudian menghasilkan 4 kemungkinan strategi yaitu: (Dyson, 2003; Mooney, 2001)

1) Strategi SO, yakni strategi untuk menggunakan kekuatan dengan memanfaatkan peluang

2) Strategi WO, yakni strategi untuk meminimalkan kelemahan dengan memanfaatkan peluang

3) Strategi ST, yakni strategi untuk menggunakan kekuatan dalam mengatasi ancaman

4) Strategi WT, yakni strategi untuk meminimalkan kelemahan dan menghindari ancaman.

Matriks SWOT disajikan pada Gambar 2.

e. Quantitative Strategic Planning Matrix (QSPM)

QSPM merupakan hasil keputusan strategis setelah menilai skor kemenarikan (Attractiveness Score/AS) setiap faktor strategis baik faktor internal maupun eksternal (Sarkis, 2003:81-90). Dari hasil skor pembobotan dikalikan tingkat kemenarikan diperoleh skor kemenarikan total (Total Attractiveness Score/TAS) yang disajikan dalam Tabel 5.

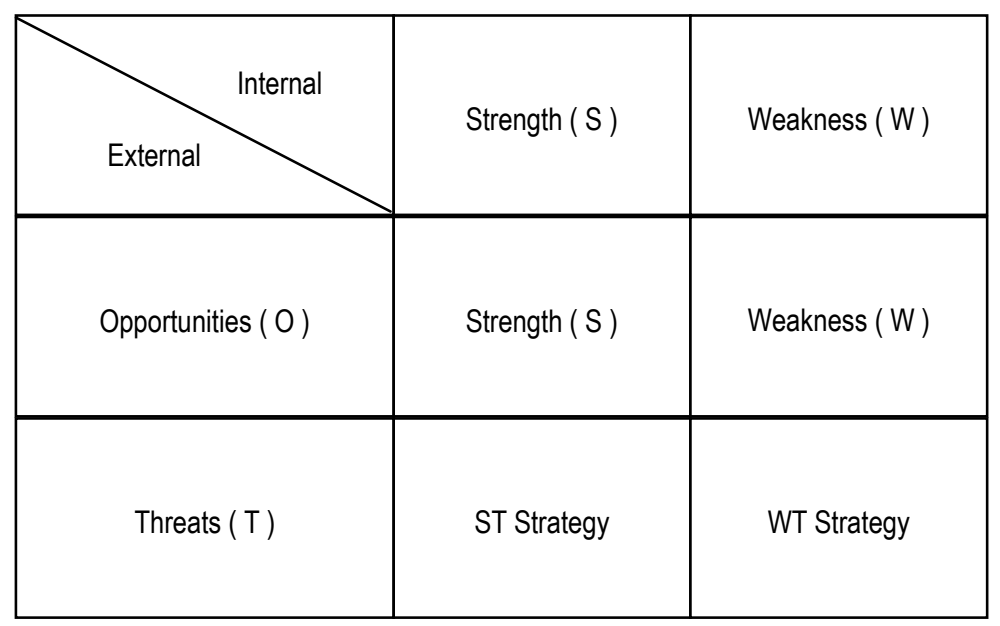

Gambar 2. Matriks SWOT 
Tabel 5. Quantitative Strategic Planning Matrix (QSPM)

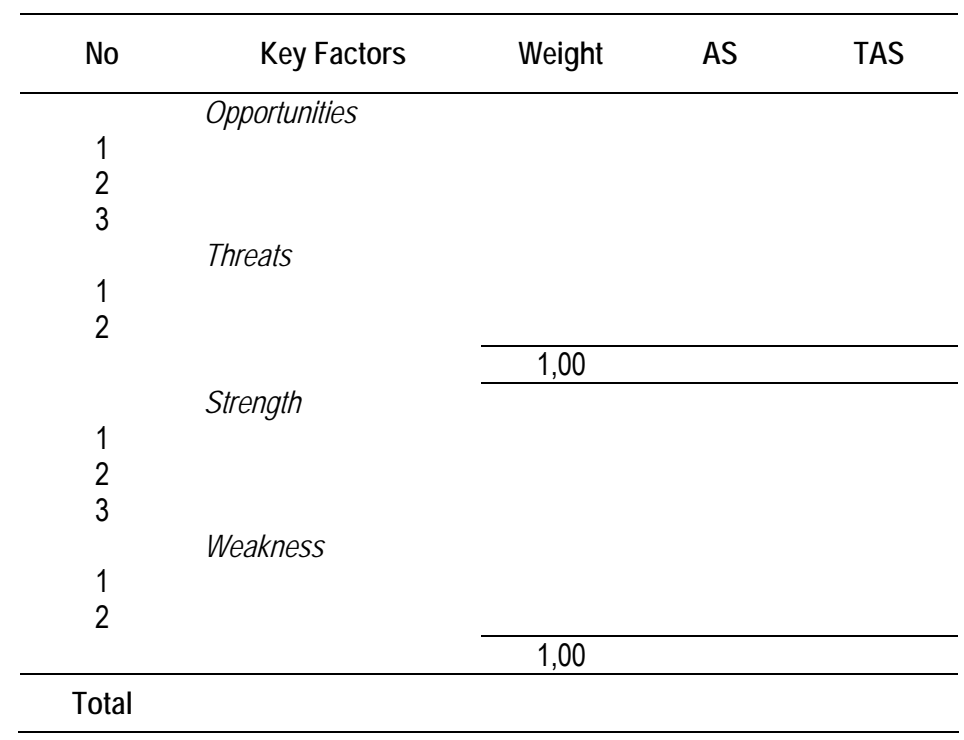

AS : Attractiveness Score, TAS : Total Attractiveness Score

\section{HASIL DAN PEMBAHASAN}

Hasil analisis yang dilakukan berdasar penilaian bobot, rating, dan skor setiap faktor lingkungan eksternal dan internal menunjuk- kan kondisi sebagaimana disajikan dalam tabel EFE dan IFE, IE matriks, SWOT matriks, dan QSPM yang secara berturutturut dijelaskan berikut ini.

\section{Matrix External Factor Evalution (EFE)}

\begin{tabular}{lccc}
\hline External Key Factors & Weight & Rating & Score \\
\hline $\begin{array}{l}\text { Peluang: } \\
\text { 1. Loyalitas masyarakat terhadap adanya Objek PAD yang perlu }\end{array}$ & & & \\
$\quad$ dikembangkan & 0,080 & 4 & 0,320 \\
2. Dukungan masyarakat sekitar objek PAD & 0,080 & 4 & 0,320 \\
3. Dukungan tokoh masyarakat terhadap pungutan pajak dan retribusi & 0,080 & 3 & 0,240 \\
4. Kerjasama lintar sektor & 0,056 & 1 & 0,056 \\
5. Kerjasama lintas program & 0,100 & 3 & 0,300 \\
6. Kebijakan Pemerintah Daerah dalam peningkatan PAD & 0,100 & 4 & 0,400 \\
& & & \\
Ancaman: & & & \\
1. Tuntutan terhadap mutu pelayanan pajak dan retribusi & 0,051 & 1 & 0,051 \\
2. Kurangnya kesadaran wajib pajak/retribusi & 0,120 & 4 & 0,480 \\
3. Kualitas SDM penarik pajak/retribusi & 0,121 & 4 & 0,484
\end{tabular}


4. Situasi Perekonomian (krisis)

$0,050 \quad 1 \quad 0,050$

5. Pengaruh kebijakan politik pemerintahan

$0,060 \quad 4 \quad 0,240$

6. Kurangnya ketersediaan biaya operasional

$0,051 \quad 1 \quad 0,051$

7. Pengaruh peraturan yang kurang konsisten dengan kondisi daerah

0,051

0,051

\section{Total}

1,00

3,043

2. Matrix Internal Factor Evalution (IFE)

\begin{tabular}{lccc}
\hline Internal Key Factors & Weight & Rating & Score \\
\hline Peluang: & & & \\
1. Tersedianya personil pengelola sumber PAD & 0,150 & 4 & 0,600 \\
2. Pendidikan personil pengelola PAD cukup & 0,077 & 4 & 0,298 \\
3. Lingkungan kerja yang baik & 0,046 & 1 & 0,046 \\
4. Sistem dan prosedur yang jelas & 0,072 & 4 & 0,288 \\
5. Standar pelayanan minimal & 0,043 & 1 & 0,043 \\
6. Sarana/prasarana yang cukup & 0,036 & 1 & 0,036 \\
7. Kemampuan keuangan untuk mengelola administrasi PAD & 0,060 & 3 & 0,180 \\
8. Struktur Organisasi pengelola PAD yang jelas & 0,036 & 1 & 0,036 \\
9. Tupoksi yang jelas & 0,065 & 3 & 0,195 \\
Kelemahan: & & & \\
1. Kurangnya personil sesuai bidangnya & & & \\
2. Ketrampilan sebagian personil terbatas & 0,046 & 1 & 0,046 \\
3. Jauhnya letak lokasi objek pajak/retribusi & 0,060 & 3 & 0,180 \\
4. Pelaksanaan sistem dan prosedur sering ada hambatan & 0,060 & 1 & 0,180 \\
5. Penarikan pajak/retribusi tidak memahami standar pelayanan & 0,046 & 2 & 0,046 \\
$\quad$ minimal & 0,051 & 2 & 0,102 \\
6. Sebagian sarana/prasarana kualitasnya menurun & & & \\
7. Terbatasnya dana untuk operasional penarikan PAD & 0,048 & 2 & 0,096 \\
8. Tumpang tindihnya Tupoksi dari pengelola PAD & 0,051 & 2 & 0,102 \\
& 0,053 & 2 & 0,106 \\
\hline T o t a I & & & \\
\hline
\end{tabular}

\section{External-Internal Matrix (EI Matrix)}

Atas dasar analisis yang dilakukan terhadap faktor eksternal dan internal yang diringkas dalam matrik EFE dan IFE di muka, maka dapat disusun EI Matrix dengan mempertemukan nilai skor pada kedua matrix tersebut. Dengan demikian dalam matriks EI ini diperoleh perbandingan $\mathrm{EFE}$ : $\mathrm{IFE}=3,043$ :
2,580 jatuh pada sel I dan V. Hal ini mengandung arti bahwa Dipenda Kabupaten Batang sebagai pengelola PAD perlu menerapkan strategi peningkatan PAD melalui EFE dan mempertahankan strategi melalui IFE. 


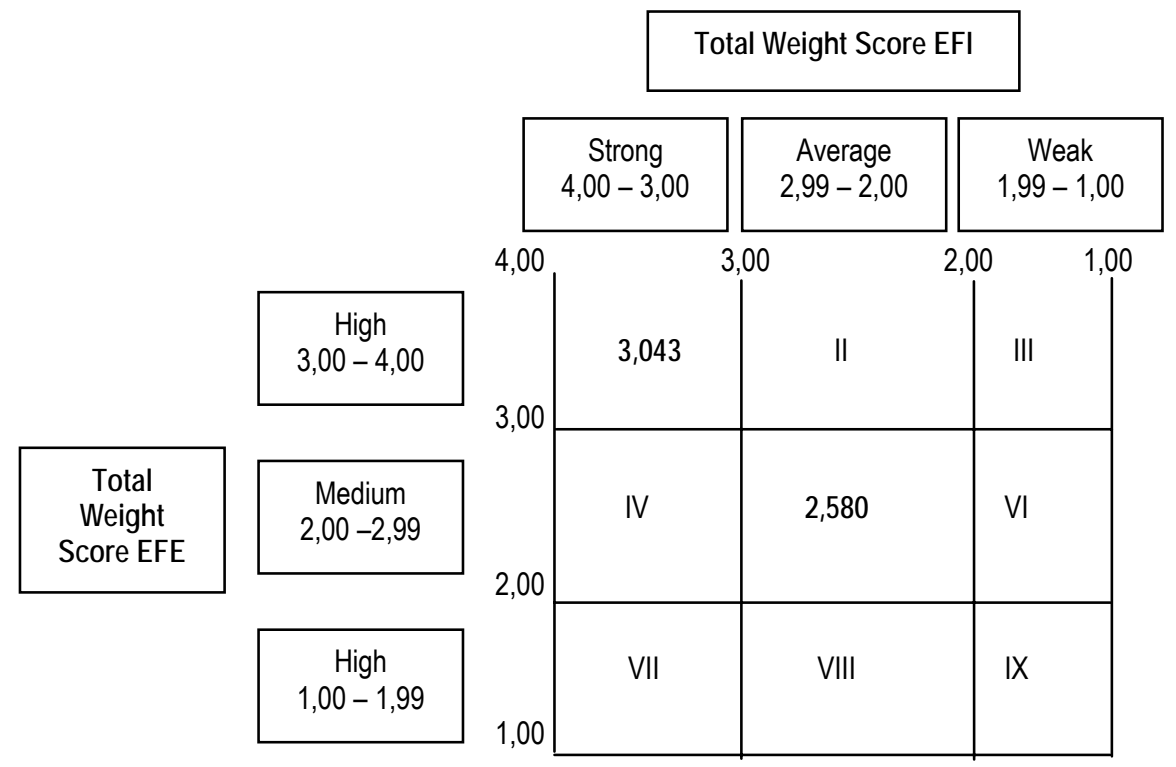

Gambar 3. External - Internal Matrix ( El Matrix )

\section{Analisis SWOT}

Hasil penjabaran dari matriks SWOT dapat dijelaskan keempat strategi berikut;

\section{Strategi SO:}

- Meningkatkan loyalitas masyarakat dan pengelola PAD

- Meningkatkan kualitas pengelola PAD

- Meningkatkan kerjasama lintassektor dan lintasprogram

- Meningkatkan sinkronisasi program dan kegiatan sesuai Tupoksi

- Menerapkan kebijakan standar pelayanan minimal

\section{Strategi WO:}

- Menambah jumlah personil pengelola PAD
- Meningkatkan ketrampilan pemungut pajak/retribusi

- Memperbaiki kondisi lingkungan kerja dengan menerapkan sistem kerjasama antarbagian sektor

- Menerapkan koordinasi dalam kebijakan pelaksanaan Tupoksi

- Meningkatkan kemampuan keuangan untuk mengelola obyek PAD

\section{Strategi ST:}

- Meningkatkan kualitas pelayanan dengan menerapkan standar pelayanan minimal

- Sosialisasi sistem dan prosedur penarikan PAD

- Menempatkan personil pemungut PAD sesuai dengan disiplin ilmunya

- Meminimalkan pengaruh negatif kebijakan politik lokal 
- Sinkronisasi peraturan sesuai dengan potensi dan kondisi daerah

\section{Strategi WT:}

- Meningkatkan kualitas SDM pemungut pajak/retribusi

- Meningkatkan sarana mobilitas bagi pemungut pajak/retribusi

- Meningkatkan koordinasi antarsektor dan bagian
- Meningkatkan anggaran biaya operasional

\section{Analisis QSPM}

Hasil pembobotan dan penilaian skor kemenarikan faktor strategis internal dan eksternal sebagai alternatif keputusan strategi terbaik yang harus segera dilaksanakan dalam analisis QSPM sebagai berikut;

\section{Matrix External Factor Evaluation (EFE)}

\begin{tabular}{llll}
\hline Strategic Key Factors & Weight & AS & TAS \\
\hline Kekuatan: & & & \\
1. Tersedianya personil pengelola sumber PAD & 0,150 & 3 & 0,450 \\
2. Pendidikan personil pengelola PAD cukup & 0,077 & 3 & 0,231 \\
3. Lingkungan kerja yang baik & 0,046 & 2 & 0,092 \\
4. Sisem dan prosedur yang jelas & 0,072 & 3 & 0,216 \\
5. Standar pelayanan minimal & 0,043 & 2 & 0,086 \\
6. Sarana / prasarana yang cukup & 0,036 & 1 & 0,036 \\
7. Kemampuan keuangan untuk mengelola administrasi PAD & 0,060 & 2 & 0,120 \\
8. Struktur Organisasi pengelola PAD yang jelas & 0,036 & 1 & 0,036 \\
9. Tupoksi yang jelas & 0,065 & 3 & 0,195 \\
Kelemahan: & & & \\
1. Kurangnya personil sesuai bidangnya & & & \\
2. Ketrampilan sebagian personil terbatas & 0,046 & 2 & 0,092 \\
3. Jauhnya letak lokasi objek pajak / retribusi & 0,060 & 2 & 0,120 \\
4. Pelaksanaan sistem dan prosedur sering ada hambatan & 0,060 & 2 & 0,120 \\
5. Penarik pajak / retribusi tidak memahami standar pelayanan & 0,046 & 2 & 0,092 \\
minimal & 0,051 & 2 & 0,102 \\
6. Sebagian sarana / prasarana kualitasnya menurun & 0,048 & 2 & 0,096 \\
7. Terbatasnya dana untuk operasional penarikan PAD & 0,051 & 2 & 0,102 \\
8. Tumpang tindihnya Tupoksi dari pengelola PAD & 0,053 & 2 & 0,106 \\
T o t a I & & & \\
\hline
\end{tabular}




\section{Peluang:}

1. Loyalitas masyarakat terhadap adanya objek PAD yang perlu dikembangkan

2. Dukungan masyarakat sekitar objek PAD

$\quad 4 \quad 0,320$

3. Dukungan tokoh masyarakat terhadap pungutan pajak dan retribusi

$0,080 \quad 4 \quad 0,320$

4. Kerjasama lintas sektor

$0,080 \quad 3 \quad 0,240$

5. Kerjasama lintas program

$0,056 \quad 1 \quad 0,056$

6. Kebijakan Pemerintah Daerah dalam peningkatan PAD

$0,100 \quad 3 \quad 0,300$

$0,100 \quad 4 \quad 0,400$

\section{Ancaman:}

1. Tuntutan terhadap mutu pelayanan pajak dan retribusi $\quad 0,051 \quad 1 \quad 0,051$

2. Kurangnya kesadaran wajib pajak / retribusi $\quad 0,120 \quad 0 \quad 4 \quad 0,480$

3. Kualitas SDM penarik pajak / retribusi $\quad 0,121 \quad 4 \quad 0,484$

$\begin{array}{llll}\text { 4. Situasi Perekonomian (krisis) } & 0,050 & 1 & 0,050\end{array}$

$\begin{array}{llll}\text { 5. Pengaruh kebijakan politik pemerintahan } & 0,060 & 4 & 0,240\end{array}$

$\begin{array}{llll}\text { 6. Kurangnya ketersediaan biaya operasional } & 0,051 & 1 & 0,051\end{array}$

$\begin{array}{lllll}\text { 7. Pengaruh peraturan yang kurang konsisten dengan kondisi daerah } & 0,051 & 1 & 0,051\end{array}$

Total

1,000

Hasil analisis terhadap skor kemenarikan dari semua faktor strategis yang dijelaskan dalam QSPM tersebut menunjukkan bahwa total skor kemenarikan (TAS) pada faktor eksternal $(3,029)$ adalah lebih besar dari TAS faktor internal $(2,292)$. Hal ini menunjukkan bahwa keputusan strategi yang tepat untuk meningkatkan PAD Kabupaten Batang adalah dengan strategi ekstensifikasi. (Dianto, 2000)

Kemudian pada daftar faktor strategis eksternal diperoleh nilai TAS terbesar pada kualitas pemungut pajak/retribusi $(0,484)$. Hasil ini mengindikasikan bahwa strategi ekstensifikasi yang dapat segera dilaksanakan secara lebih spesifik adalah strategi peningkatan kualitas SDM pemungut pajak/ retribusi daerah.

Jadi, Dipenda Kabupaten Batang dapat merumuskan keputusan strategi terbaik dari hasil analisis QSPM ini yakni untuk meningkatkan PAD pada masa mendatang dapat dilakukan strategi ekstensifikasi pada peningkatan kualitas SDM pemungut pajak/retribusi.

\section{KESIMPULAN}

Setelah melakukan serangkaian analisis dengan pendekatan-pendekatan di muka, dapat ditarik simpulan dari penelitian ini, yakni:

1. Dari analisis IE matriks, diperoleh angka skor EFE 3,043 dan IEF 2,580 dan jatuh pada sel I dan V (sel pertumbuhan dan memelihara). Dengan demikian dapat disimpulkan bahwa upaya peningkatan PAD yang sekarang ini dilakukan oleh Dipenda Kabupaten Batang belum sesuai dengan potensi dan peluang yang ada. 
2. Jika dikonsultasikan dengan hasil analisis SWOT, kondisi pada simpulan 1 tersebut menunjukkan bahwa strategi yang digunakan sekarang belum sesuai dengan strategi SO, yaitu menggunakan kekuatan untuk memanfaatkan peluang.

3. Hasil analisis QSPM menunjukkan bahwa angka TAS pada faktor strategis eksternal sebesar 3,029 adalah lebih besar dibandingkan dengan angka TAS pada faktor strategis internal yakni sebesar 2,292. Angka ini menunjukkan bahwa strategis peningkatan PAD Kabupaten Batang yang tepat untuk dilaksanakan adalah "strategis ekstensifikasi”.

4. Keputusan strategi yang dapat segera dilaksanakan sesuai dengan skor kemenarikan setiap faktor strategis eksternal ternyata angka tertinggi ada faktor kualitas SDM pemungut pajak/retribusi $(0,484)$. Hal ini mengandung arti bahwa strategi eksternal yang spesifik untuk segera dilaksanakan adalah "strategi peningkatan kualitas SDM pemungut pajak/retribusi daerah.

\section{DAFTAR PUSTAKA}

David, Fred R., (2001). Strategic Management, Concept, and Cases, New Jersey: Prentice Hall.

Dewi, Elita, (2002). Identifikasi Sumber Pendapatan Asli Daerah dalam Rangka Pelaksanaan Otonomi Daerah, Makalah
Seminar Digital Universitas Sumatera Utara.

Dianto, M. (2000). Upaya yang Dilakukan Daerah untuk Peningkatan PAD, Yogyakarta: Program Pascasarjana UGM.

Dyson, Robert G., (2003). Strategic Development and SWOT Analysis at the University of Warwick, European Journal of Operational Research Vol. 152, (3), 631-640.

Halim, Abdul, (2001). Manajemen Keuangan Daerah, Yogyakarta: UPP AMP YKPN

Mooney, Dick, (2001). SWOT Analysis - A Structured Way to Plan, Communicator, Vol. 2 (4).

Muluk, Khairul, (2003). Kinerja Lima-E, Keuangan Publik, Jurnal Forum Inovasi, Vol 1(2), Jakarta.

Sarkis, Joseph, (2003). Quantitative Models for Performance Measurement Systems - Alternate Considerations (Quantitative Strategic Planning Matrix/QSPM). International Journal of Production Economics. Vol. 86, (1), 81-90.

Setiawan, Rudie (2005) Perumusan Strategi Bisnis dengan Menggunakan Metode QSPM (Quantitative Strategic Planning Matrix): Studi Kasus pada Hotel " $X$ " di Bandung, Tesis Magister Manajemen Bisnis dan Administrasi Teknologi. Bidang Khusus Bisnis Manufaktur, Bandung. 